\title{
Memory regimes, struggles over resources and ethnogenesis in the Brazilian Amazon
}

Edviges M. Ioris

'Universidade Federal de Santa Catarina, Florianópolis/SC, Brasil

\begin{abstract}
The paper focuses on the ethnogenesis processes that emerged in the late 199os in the Brazilian Amazon region, more specifically among indigenous peoples in the lower Tapajós region, in southwestern Pará. Highlighting the case of the Munduruku, alongside the Borary and Arapium, the paper approaches these ethnogeneses as constituting a new memory regime that provides the indigenous peoples with a counternarrative to the ways that historiography and the jurisdictions of the dominant power have not only omitted, over time, but that also negated the permanence of ethnic and cultural alterities in the region. Confronting historiographical narratives that, since the mid-nineteenth century, have confirmed their disappearance from the lower Tapajós region, the indigenous peoples arrive at the turn of the twenty-first century presenting a counter-narrative to the erasure of their existence, re-establishing their presence in history of the lower Tapajós, and asserting their demands in negotiations of power. The paper also examines the motivations (material and ideological) precipitating the emergence of these ethnogenesis processes, which have taken shape in a field of disputes strongly defined by the interests of the timber industry.
\end{abstract}

Keywords: ethnogenesis; memory regime; ethnic identity; Amazon/lower Tapajós River. 


\section{Regimes de memória, conflitos sobre recursos e etnogêneses na Amazônia}

\section{Resumo}

Este texto focaliza os processos de etnogênenes que despontaram no final da década de 1990 na Amazônia, especificamente entre os grupos indígenas na região do baixo rio Tapajós, no sudoeste do estado do Pará. Ressaltando o caso dos indígenas Munduruku, ao lado dos Borary e Arapium, o texto procura pensar estas etnogêneses como constituindo um novo regime de memória, que confere aos indígenas uma contra narrativa aos modos como a historiografia e as instâncias do poder dominante têm, ao longo do tempo, não só omitido como renegado a permanência das alteridades étnicas e culturais na região. Confrontando as narrativas historiográficas que, desde meados do século XIX, afirmavam o seu desaparecimento no baixo Tapajós, os indígenas aportam na virada para o século XXI com uma contra narrativa ao do apagamento de sua existência, recolocando sua presença novamente na história do baixo Tapajós, e fazendo valer suas demandas nas negociações do poder. O texto procura ainda compreender as motivações (materiais e ideológicas), que alavancaram esses processos de etnogêneses, os quais se conformaram em um campo de disputas fortemente marcado por interesses do setor madeireiro.

Palavras-chave: etnogênese; regime de memória; identidades étnicas; Amazônia/baixo Tapajós. 


\title{
Memory regimes, struggles over resources and ethnogenesis in the Brazilian Amazon
}

\author{
Edviges M. loris
}

\section{On judges and Indians: ethnic and cultural differentiations in the lower Tapajós}

Stunned, the Borary and Arapium indigenous peoples learned that on November $26^{\text {th }}$, 2014, Judge Airton Portela of the Federal Court of Santarém in western Pará State had ruled that the report produced by the National Indian Foundation (FUNAI), identifying and delimiting the Maró Indigenous Territory, had no legal validity and that FUNAI should cease the demarcation procedures that were in progress. It thus revoked FUNAI's decree that recognised this indigenous territory as traditionally occupied by the Borary and Arapium, published in 2011. The judge's ruling was in response to the action brought by representatives of community associations of peasant groups residing in areas adjacent to these peoples, who said they were against the demarcation procedures for this Indigenous Territory, arguing that ties between the Indians and the respective ethnic groups that they claimed to belong to did not exist. Accepting the petition of the plaintiffs of the action, the judge ruled that the Maró Indigenous Territory demarcation process was null, judging that its inhabitants were not "Indians" but merely "traditional riverside populations" (p.103), and therefore not subject to Indigenous Rights.

The judge's decision generated a strong reaction on the part of the Indians, who protested in front of the Federal Public Prosecutor's offices (Ministério Público Federal, MPF) in Santarém, demanding that an appeal be made. The Committee for Indigenous Affairs of the Brazilian Association of Anthropology (CAI/ $\mathrm{ABA}$ ) issued a note of repudiation, together with other indigenous support organisations, denouncing it as premeditated in serving the interests of logging companies that were exploiting the forests on indigenous lands, and that, in fact, they were behind the action. The MPF of Santarém appealed the sentence, and it ended up being annulled by another judge who recognised the rights of the indigenous people.

The argumentative narrative of Judge Portela, clarified in 106 pages, offers questions of the utmost importance when considering the relationship of legal authorities with indigenous peoples in Brazil, as well as other themes that are dear to anthropology, such as ethnogenesis, miscegenation, and ethnicity, to cite the most evident aspects discussed in the argument against ethnic identification of indigenous peoples. Their problematisation also parallels the case of the Mashpee Indians in their disputes to prove to the US Supreme Court, in the 1970s, the continuity of their references and ethnicities, which were crucial to securing dominion over their territories (Clifford 1988). However, for the time being, two points should be emphasised. First, the sentence does not innovate by decreeing the nonexistence of indigenous peoples distinct from the rest of the Amazonian and Brazilian society in the region of the lower Tapajós River. ${ }^{1}$ Such a position can be found both in historical understandings produced about the region and within the larger strategies of power that transpire to make invisible and to proscribe the existence and differentiated modes of ethnic and cultural organisation. Despite the initial descriptions, after barely two centuries of colonisation of the Tapajós valley, the existence of the numerous and ethnically diversified peoples found

\footnotetext{
The lower Tapajós River region is located in the southwest of the state of Pará, in an area classified by the Brazilian Historical and Geographical Institute as the Médio Amazonas Paraense micro-region, more commonly known as the Lower Amazon.
} 
at the mouth of the Tapajós valley when the first Portuguese ships arrived in the region in the seventeenth century — the Tupinambá, Tapajó, Arapium, Borary, Corarienses, Comandy, Maytapu, among others- was no longer recorded ${ }^{2}$ (Santos 1999; Parker 1985; Menéndez 1992; 1981; Bates 1979 [1863]; Ribeiro 1979; Meggers 1977; Nimuendaju 1949).

Since the late eighteenth century, after the expulsion of the Jesuits who had dominated the region of the lower Tapajós for a century, when they are referenced, the native peoples are systematically described by the generic terms "Indian" or "indigenous", without reference to their ethnicities. In his famous compendium, produced in the mid-183os, Portuguese military man Antonio Ladislau M Baena (2004 [1839]) was the first to account for the number and racial classification of the population of the State of Grão-Pará. Despite recognising that in the Tapajós region it was the "Indians who make up the greatest numerical strength of the population, and the only resource for the country's work" (p.221), he did not specify any of their ethnic groups, rather they were listed in the general tally as "free", together with the "whites", as opposed to "slaves". The naturalistic travellers who sailed along the Tapajós River in the nineteenth century acted similarly. Although they identified the natives they encountered, and who served them, as "Indians", they did not register any ethnic nominations, except for a Munduruku family on the Cupari River, and further afield on the upper Tapajós (Bates 1979 [1863]; Condreau 1977 [1897]). Later, in the twentieth century, these groups became known as part of an Amazonian peasantry and began to be referred to as "caboclo" or "riverside people", categories whose definitions tend to severely disqualify important possible links to different ethnic or territorial affiliations (Ioris 2014; Lins e Silva 1980).

Thus, the second point of emphasis regarding the judge's ruling is how this denial of ethnic recognition of the Borary and Arapium peoples, proscribing territorial rights, reflects (and composes) the field of disputes that has been constituted since the end of the last century, with the emergence of ethnic and territorial reaffirmation processes among several indigenous communities in the lower Tapajós region (Mota 2006; Ioris 2014, 2005; Bolanõs 2008 Vaz 2010; Lima 2015; Peixoto 2017). This movement first began among the Munduruku of Taquara, who are located within the dominion of the Tapajós National Forest (Flona Tapajós), on the right bank of the Tapajós River. In 1998, representatives of the Taquara people sought the offices of the FUNAI in Itaituba, on the upper Tapajós, to inquire about their rights in relation to the demarcation of their lands, since these were under the control of the Flona Tapajós and managed by the Brazilian Institute of the Environment and Renewable Natural Resources (IBAMA) (Ioris 2014; 2005). Attended by FUNAI technicians, who recognised the legitimacy of the demand and provided administrative measures, the Taquara Indians firmly engaged in the proposal of re-elaborating their ways of life and organisation, so that they were aware of how their origins and indigenous references were comprised, and claimed that they belonged to the Munduruku ethnic group. Inside the Flona Tapajós, the communities of Bragança and Marituba joined soon after Taquara, also affirming themselves as Munduruku, constituting what anthropology has defined as processes of ethnogenesis (Bartolomé 2006; Pacheco de Oliveira 1999; Sider 1976).

Influenced by the process of ethnogenesis taking shape among the Munduruku in the Flona Tapajós, several other domestic groups from various communities throughout the lower Tapajós River and Arapiuns River region also began to reaffirm belonging to ethnicities that historical literature claimed no longer existed, such as the Borary, Arapium, Tapajó, Maytapu, Tupayú, Kumaruara and Tupinambá. Together these groups, an estimated five thousand people, have engendered a process of reconstruction of their indigenous identities and ancient cultural traditions, reclaiming ritual manifestations, language,

\footnotetext{
2 As an example, in one of the earliest records concerning Indians at the mouth of the Tapajós River, made by Maurício de Heriarte, a chronicler who accompanied the Pedro Teixeira expedition through the Amazon in 1628, he counted "6o,ooo men of war". For a mapping of the various ethnic groups in the lower Tapajós region from the 16th to the 18th centuries, see Menéndez (1992; 1981).
} 
body paintings, as well as demanding the demarcation of their lands and constructing forms of political organisation based on ethnicity.

In two decades of mobilisation, these indigenous peoples have won the recognition of four Indigenous Lands, ${ }^{3}$ promoting a significant reconfiguration in the socio-cultural and spatial landscape of the region, and reinserting ethnic-indigenous issues within the framework of local power discussions and relationships. The socio-political context that was shaped by this ethnic movement can be understood as a semantic field of ethnicity, in the sense Valle (1999) also observed among the Tremembé, in which new forms of discursiveness of unequal political weight are initiated regarding the new ethnicity that has been instigated. In the valley of the lower Tapajós, the once predominantly idyllic vision of the Tapajós peoples -widely exalted in songs, dances, literature, cuisine, in local myths, archaeological sites or shards of sophisticated ceramics that abound in black soils of the so-called "Indian black earth", bearing witness to the long, intense and elaborate indigenous occupation - had been conversely based on the firm conviction of their past condition and subsequent disappearance, which had occurred as a consequence of the colonial encounter. The emergence of the ethnic reassertion movements that arose at the turn of the twenty-first century has reconfigured and brought to the life, and to the field of local socio-political relationships, the existence of indigenous groups that are now organised and empowered to assert their rights. However, while indigenous people have been relatively successful in several spheres of power, from the municipal to the federal level, in articulating demands at the negotiating table, this has also resulted in conflicts, disputes, discursive productions (for and against Indians), strategies of political alliances and articulations, re-elaborations of historical understandings and of belonging.

Thus, I return to previous discussions on the ethnic and cultural re-elaboration movement among the indigenous people in the region of the lower Tapajós River, which I have followed from the beginning, particularly among the Munduruku in the Flona Tapajós. This text seeks to consider how these movements of ethnogenesis confer a counter-narrative to the ways that historiography and the jurisdictions of the dominant power have not only omitted, over time, but that also negated the permanence of ethnic and cultural differentiations. They contribute as a counter-narrative to the erasure, re-establishing the indigenous existence within the history of the lower Tapajós, and articulating their demands at the negotiating tables of power, from the local to the national level. This relocation of indigenous peoples in history can be thought of as a process of constructing a new memory regime, in the terms Pacheco de Oliveira (2016) presents us, so as to understand the manner these peoples are conceiving and constructing memory in contemporaneity, in which they "are the main architects" (p. 29), to counter the official narratives that have excluded their protagonism in the formation of Brazil. In this new memory regime, cultural actions and ritual performances not only constitute ways of reworking memory and rewriting history, but also empowerment and the expression of their alterity.

\section{Between idealisations and erasures: Indigenous peoples outside history}

In previous discussions (Ioris 2017, 2011), I have already highlighted how historiography had terminated the presence of ethnically articulated groups in the region of the middle and lower Tapajós

\footnotetext{
3 "Indigenous Land" (Terra Indígena) is a state reserve category designated to indigenous people in Brazil, which circumscribe an area of their historical territory. The Indigenous Lands in the lower Tapajós recognised up to now, the Munduruku-Taquara Indigenous Land and Bragança-Marituba Indigenous Land, both underwent identification and delimitation studies in 2003, followed by FUNAI ordinances in 2009, and by the Minister of Justice in 2016. The Maró Indigenous Land underwent identification and delimitation studies in 2008, followed by a FUNAI ordinance in 2011. The Cobra Grande Indigenous Land underwent identification and delimitation studies in 2008, followed by a FUNAI ordinance in 2015. In addition, identification studies were conducted for the Mundukuru, located on the right bank of the Tapajós River, on the southern border of the Tapajós-Arapiuns Extractive Reserve, but the summary of this report has never been published. Several surveys were also conducted among the indigenous peoples who live inside the Tapajós-Arapiuns Extractive Reserve.

4 Amazonian Dark Earths; previously also called "Terra Preta do Indio" [Indian Black Earth], are strips of anthropogenic soils resulting from a long and intense process of human occupation. Every centimetre in depth is taken to indicate ten years of occupation (Moran 1990, Smith 1980, Nimuendaju 1949).
} 
valley, without at least some measure of understanding of how this process came about. It did so with minimal understanding of who they were and what happened to the diversity of indigenous peoples that were recorded by the first colonisers when they entered the mouth of the Tapajós River at the beginning of seventeenth century, to impose their occupation and domination. Regarding the Tapajó people who, along with the Tupinambá, numerically, politically and culturally dominated the lower Tapajós region when colonisation began, Nimuendajú (1949: 98) regretted that "of the Tapajó language we only know three proper names: that of the tribe, that of the chief, Orucura, and that of the devil: Aura". Betty Meggers (1977), who conducted archaeological studies in the Amazon region in the 1960s, stated that all that was known about the Tapajós linguistic affiliation was that "it was not Tupi" (p.132). Nimuendajú thought that they had ceased to exist in 1723, when they accompanied the Jesuits' transfer of the Tapajó Mission to the region of the Arapiuns River, a tributary of the Tapajós: "Thus, it seems that the Tapajó and Urucucú ceased to exist as tribes" (p. 55). He also reported that "the last time the name of the Tapajó and Urucucu tribes was found on the list of indigenous tribes of the Tapajós River [was] provided by Ricardo Franco de Almeida Serra in 1799" (p. 55). Regarding the Tupinambá, Menendez (1992: 318), in turn, reported that "thirty years after the catechesis began in the region, there was little left of the populous village at the mouth of the Tapajos, and at that time [1690] the Tupinambá were no longer spoken of as an ethnic group". Founded in 1661, the Tapajó Mission quickly became the most important in the Province of Grão-Pará and Maranhão, bringing together diverse groups of Tapajó, Tupinambá, Arapium, Corarienses and Comandy. However, as a result of the conflicts with settlers for the control of the indigenous people, this mission was transferred to the Arapiuns River in 1723, when Nimuendaju assumed the Tapajó people vanished.

Similarly, if there is a very little knowledge concerning the indigenous peoples and their forms of sociopolitical and cultural organisation, then even less is known concerning the hundred years of domination of the Jesuit missions in the lower Tapajós between the seventeenth and eighteenth centuries. Jesuit Missions were established in five different location $s^{5}$ along the Tapajós River, where indigenous peoples of various language families were confined (Menéndez 1992, 1981), and Nheengat $u^{6}$ became the official language. Likewise, there is very little knowledge about the extension of the Pombaline policies of the Indian Directorate that succeeded them in the mid-eighteenth century, instituted by the Governor of the Captaincy of Grão-Pará, Mendonça Furtado, who sailed the Tapajós in 1758 to demarcate borders and the establishment of new "villages" and "places" that had replaced the banned Jesuit missions. The names of villages, such as Vila de Boim and Vila Franca, are current reminders of the institution of this colonial act. However, the participation of indigenous peoples in this State policy, whose goal and strategy was the miscegenation of the native population, and its meaning for them still awaits careful research and analysis.

There is also a critical lack of knowledge regarding indigenous participation in the Cabanagem revolt, which took place most intensely from 1835 to 1838 , constituting a violent field of battles that devastated the native population, during the conflicts or the subsequent repression (Bessa Freire 2011; Harris 2010; Lima 2008; Di Paolo 199o; Parker 1985; Moreira Neto 1988). Santarém, Vila Franca, Alter do Chão and Pinhél, places where the Jesuit missions had been founded, constituted important strongholds for the struggle and resistance of "cabanos", the native combatants in the revolt, as did Ecuipiranga, located on the bank of the Amazon River and connected to the Tapajós by land (Vaz 2010). In Pinhél, where the Maytapu people are

\footnotetext{
5 In 1661, the Tapajó Mission was founded at the mouth of the Tapajós River, where the city of Santarém is currently located. As missionary activity spread along the Tapajós between 1722 and 1740, the Jesuits founded three more missions in the region. The first in 1722, São José dos Maitapu, located some 18o km south of Santarém, on the left bank of the Tapajós, where the village of Pinhél is located today. The Indians who live there identify themselves as Maytapú. In 1723, the Iburari, or Borary, Mission, currently Alter do Chão, was founded on the right bank of the Tapajós. For some time, this mission was merely an extension of the Tapajó Mission and it only became independent in 1723, the same year that the latter was transferred to Arapiuns. The Indians who live there identify themselves as Borary. In 1740, the Mission of Saint Ignatius, or the Tupinambaranas Mission, was founded on the left bank of the Tapajós, where Vila de Boim is now located.

6 Nheengatu, or General Amazonian Language (Língua Geral Amazônica), is the Tupi-Guarani pidgin promoted by the Jesuits.
} 
located, there are still several spaces hollowed out in the ground, which are attributed to combat trenches built during the revolt, together with detailed narratives about confrontations and the participation of their ancestors in them?

Even though we know that indigenous participation was significant in the lower Tapajós, and that local narratives are full of references to it, in historiographical terms, it tends to appear as the generic "Tapuia", usually disqualified in terms of ethnic belonging or distinction, except for the Munduruku (Harris 2010, Menéndez 1992, Bates 1979 [1863]). While highlighting the massive participation of native peoples in the Cabanagem, for example, Menendez (1992: 22) describes those who fought alongside the cabanos as "previously detribalised Indigenous, "descidos" [displaced] or descended from "descidos", whose original villages no longer existed. They were part of this "Tapuia" population interned in small groups with their tuxauas, who joined the cabanos" (author's emphasis). The manner in which the author identifies the Indians who participated in the Cabanagem similarly tends to reinforce the vision about them as devoid of ethnic or cultural references, while also proclaiming a bigoted rupture between supposedly "real" and "acculturated", "detribalised" indigenous people, the inexorable result of contact with the coloniser.

Despite being identified as speakers of the General Amazonian Language, Nhengatu, (Bessa Freire 2011), the indigenous peoples who participated in the Cabanagem have generally been indistinctly merged in the category of a "detribalised Tapuia". Thus, we still do not know much about their ethnic and racial diversity, nor their respective participation in the movement, even though there is no lack of references of the involvement of numerous groups among the indigenous Amazonian ethnology (Vaz 2010; Harris 2010; Lima 2008; Tassinari 2003; Velthem 2003; Menéndez 1992; Amoroso 1992). The strong military repression that followed against the "cabanos" has been taken as an explanation for the final clash that had definitively annihilated indigenous existence in several regions, causing extermination and dispersion; although little is known of the manner and directions that these dispersions/migrations may have taken.

This is certainly the reality for most of the indigenous peoples who were somehow involved with the Cabanagem, notwithstanding some notable efforts at ascertaining their participation in the revolt (Harris 2010; Lima 2008). Regarding the Tapajós valley, a similar lack of studies fails to provide us with a clearer understanding of the diversity of indigenous participation, and the developments leading to the collapse of the movement. References abound indicating the involvement of many groups, whose territories bear clear signs of their struggles, and people recall rich details in their narratives, such as running away, the fears they experienced, which they attributed to the "wars". Orlando, a Munduruku leader from the village of Braganza, reminded us of how his "grandmother always told them they lived there [inside the forest] because they became afraid of the war, because there'd been war for so long. They were afraid because they saw that some people came and attacked. The whites attacked. So they preferred to run away and hide there, right, inside the forest, where no one could find them, so they wouldn't be attacked". Along the same lines, Leo Tupaiú, a Tupaiú leader of the Aningalzinho community in Arapiuns, reproduced stories he had heard from his grandmother about his ancestors. According to him, his great-grandparents Jose and Joana Tupaiú "went to live in the forest to flee the war; in there, into the forest. There, where they couldn't make a fire, day or night, so as not to draw attention. They lived in holes. They lived in holes because they were afraid they [the Brazilian army] would come and get them to be slaves, to fight in the war. Because the army would come, catch them and take them away, to the war ${ }^{8}$. Those who wouldn't go were killed. The only way was to run into the forest, where they stayed, living in a hole".

Upon listening to these narratives, it was impossible for me not to question how this image of the generic detribalised indigenous, descidos [displaced], Tapuia speaker of the general language, who had been the victims of

\footnotetext{
7 For narratives about the involvement of Pinhél in the Cabanagem revolt see the PhD thesis of Florêncio de Almeida Vaz (2010).

8 The narratives also made frequent reference to the Paraguayan war, which occurred a few years after the Cabanagem, and would also have motivated and reinforced movements to escape the conflict among the Indians.
} 
inexorable annihilation, has obscured a clearer understanding of the involvement of different indigenous peoples in the movement and their distinct modes of participation, together with official strategies towards the indigenous peoples in pacification actions and, principally, strategies of indigenous resistance.

Despite the great historical events that have taken place in the region, from the Jesuit missions in the mid-seventeenth century, to the Indian Directorate and the Cabanagem, occurring over three centuries, knowledge produced concerning the forms of interaction between the indigenous peoples and the colonisation project, and the manner of their insertion in each of these historical situations is minimal. The indigenous presence appears very distant, diluted in a simplistic narrative that triggers the inevitable realisation that, as soon as the coloniser arrived, the native peoples succumbed immediately and inexorably, without the possibility of understanding the reasons behind it. It is as if the advent of one prevailed through the radical and immediate suppression of the other.

\section{III.i Flowers that die: indigenous presence in Brazilian historiography}

In corroboration with these concerns about approaches that assume the depletion of the indigenous presence, which had succumbed to the relentless advance of the colonisation project, in his recently published book, João Pacheco de Oliveira (2016) presents a very urgent and necessary discussion on the importance of revising the dominant historiographical paradigm regarding indigenous participation in the formation of Brazil. First because, as he highlights, since the initial formulations on the history of Brazil in the nineteenth century to Marxist historians in the twentieth century, "the indigenous presence in the formation of nationality is treated in a repetitive, exoticising manner, as the exclusive product of chance, minor incidents and picturesque accounts" (p.12). In the pursuit of these formulations, he demonstrates how the historiographical narrative that was constructed concerning the formation of Brazil tended to produce an erasure of indigenous peoples and their participation with regard to the advances of the colonisation project, and later, in the nation-state project. This narrative, based on colonial categories and reifying images of an evolutionary nature, defined the place and moment in which the indigenous peoples appear within the history of Brazil: "they are prior to Brazil. Once initiated [the colonisation], the Indians could only be conceived as dying flowers, which must be described and understood before they wither and disappear. The technological and military superiority of the colonisers, the violence and the epidemics were enough to explain their extinction" (p.47-48).

The substantiation to which Pacheco de Oliveira draws attention is that this constructed narrative on the Indians - founded on an idyllic image, romanticised as a native symbol of the country, but prior to the formation of the Brazilian nation - was produced in the nineteenth century, and is directly associated with imaginative production of Brazil as nation building. More precisely, it was during the "Second Empire, when the nation-state project was elaborated based on the debates concerning migration and the end of slavery, without assigning the indigenous peoples any function other than that of native symbol, that this narrative was structured. It gained an author (Varnhagen's monumental general history) and a supporting institution (the Brazilian Historical and Geographical Institute (IHGB) in Rio de Janeiro and, subsequently, its provincial offices), and became internalised in the thinking of the elite and popular sectors" (p.50).

On the one hand, the author's critique is directed at this mode of historiographical production, which obscures the indigenous peoples as producers in the economy, dissipating them in images like small reminiscences of the autochthon of the earth, exotic, past. On the other hand, it is also directed to the anthropological modes that, in their efforts to search for diversity, for difference, have devoted themselves to studying them "as if the social organisation and cosmology of each indigenous people were isolated and autonomous systems" (p. 13); and particularly, captured "outside of history". It is in this sense that I think of the frequent ethnographies of indigenous people in the Amazon who recognise references in their narratives on the Cabanagem. However, few of them have surpassed the limits of the villages in an 
attempt to find connections between these narratives, other indigenous groups, and the wider historical events that traverse colonisation in the region. I suspect that more careful attention to the references that these narratives elicit concerning these times of "wars", of "scurrying", of fleeing, of hiding in holes, which so many went through, and which I have heard repeatedly among indigenous peoples of the lower Tapajós (Ioris 2017; 2011), will help us to understand where many of the indigenous groups that have been described as extinct may have gone. As Pacheco de Oliveira (2016:14) points out, this perspective isolated indigenous peoples and left out "the colonial world, within which the Indians lived, embedded in harsh relationships of domination - even though they exercised their agency whenever possible, putting into practice varied forms of resistance and of accommodation". Thus, it also failed to "perceive the concrete ways in which indigenous collectivities were able to resist, organise and continue to update their culture in the contemporary world, including formulating future projects".

These considerations must be the basis of the understandings of processes of ethnic and cultural re-elaboration that conform to the indigenous peoples of the lower Tapajós, of their historical processes of interaction in the colonial world, and of their gradual erasure in the historiographical narrative elaborated regarding the incorporation of the region within the national political economy. Rather than being surprised at the emergence of these processes of ethnogenesis, we should question the production of this erasure of the indigenous peoples of the region, which broadened with the consolidation of the colonisation project and the construction of the imaginary of the nation. From this past, dispersed among splintered ruins that are difficult to apprehend, we are still expected to gather the fragments, even though there is little we can infer at this time. The task is messianic; it requires awaking the dead and facing the storm of the progressive, linear narratives that have prioritised the dialectic of the victorious (Benjamin 1985). However, for more recent processes, that have occurred when we can follow them more closely, even in historical situations marked by specific processes, we continue to uncover markedly similar efforts to ensure the erasure of indigenous peoples in the region, like those expressed in Judge Portela's opinion, who ruled there was no link between the Borary and Arapium peoples and the ethnicity they identified with.

Prior to this, similar devices to deny ethnic or cultural alterities were also observed among the Munduruku of Taquara, Bragança and Marituba, in an area under the dominion of the Flona Tapajós. Such tactics are evident since the 1970s, during the clashes that the Munduruku endured following the creation of this forest reserve and subsequent attempts to forcefully remove them from their lands. During these attempts, they were also denied territorial rights and forms of identification that established their ties and belonging to broader socio-political and cultural organisations, leading to a situation of conflict that extended for more than two decades while they sought to avoid being removed from their lands. In the following sections, I focus more directly on this situation, involving the Munduruku of Taquara, Bragança and Marituba, in their struggles to ensure a cultural distinctiveness in a field of disputes strongly marked by timber industry interests in appropriating the resources of their forests. Even though I favour the situation of this indigenous people in the Flona Tapajos, the conflicts that have befallen them are directly related to those that I highlighted among the Borary and Arapium of the Maró territory. In both contexts, the conflicts over their ethnic identifications and maintenance of their territories are issues derived from this process of promoting a forest economy based on the scientific exploration and management of tropical woods, which was already in progress in the 197os in the Tapajós valley.

\section{The modern forestry project and peasant territorialities}

Although the contexts and periods are distinct, the situations experienced by the Munduruku of Taquara, Bragança and Marituba, and by the Borary and Arapium, begin with the same problematisation 
and are the result of policies encouraging the development of a large timber industry. In the lower Tapajós region, this industry was implemented in the 1970s, within the context of the military government's geopolitical project to insert the Amazon into the national political economy (Ioris 2014; 2005). As part of this program, technical cooperation agreements were established with the Food and Agriculture Organisation of the United Nations (FAO)', aimed at an extensive survey of forest resources on each side of a 10o-kilometre stretch of the Transamazon Highway. This was conducted after the Forestry Research and Development Project (PRODEPEF) ${ }^{10}$ was signed in 1971 between the Brazilian government and the United Nations Development Program (UNDP). These surveys supported the formulation of the forestry program included in the Second Amazon Development Plan (II PDAM), launched in 1974, which redefined goals and strategies for economic acceleration for the Amazon that were to be implemented through development poles in different microregions, known as Poloamazonia (Schmink and Wood 1992; Becker 1992). For the Tapajós region, the development of a modern timber industry was projected, to substitute the exploration of soft woods in flatland and wetland areas along the river, done in a way that was considered rudimentary and unproductive. In this proposition, the exploitation moved to areas of solid land, based on cutting-edge technologies, to serve the tropical timber export markets.

Also among the actions to promote forest development in the Tapajós valley, the Flona Tapajós was created on February 19, 1974, as a pilot project of a reserve for the exploitation of timber resources, very similar to those that had been created in the United States, through the US Forest Service. The Flona Tapajós was created on the same day, in a continuous decree, as the Amazon National Park, also along the Tapajós Valley, inaugurating the establishment of the first two environmental reserves in the Amazon. The technicians of the FAO team conducted the forest surveys in the Amazon, and elaborated the propositions for defining the limits of the Flona Tapajós. Thus, a national forest of about 600 thousand hectares was created, defined by the Tapajós River on its eastern boundary, the Santarém-Cuiabá highway (BR-163) on its the western boundary, and the Cupari River on its southern boundary, a few kilometres from the Transamazon Highway (BR-230). Thus, the boundaries of the Flona Tapajós are located precisely at the intersection between the two main highways that the military governments designed and constructed to interconnect roads that would conduct people from the north to the south (Santarém-Cuiabá), and from the east to the west (Transamazon) of the country.

The creation of the Flona Tapajós held grave and important consequences for all the peasant social groups that were on the lands that became the dominion of the reserve. At that time, located along the right bank of the Tapajós River ${ }^{11}$, were sixteen nuclei composed of peasant domestic groups articulated around extended families generally commanded by paternal leadership, and which each defined themselves as a "community". The "community" constituted and defined dominion over a territorial space, the limits of which resulted from agreements established between the neighbouring "communities", and boundaries renewed annually through the work of cleaning the paths that interconnected them. Developing a pattern of land occupation founded on a complex system of common resource use (Almeida 2008), the communities were also articulated around their patron saints, whose commemorative festivals created ties of alliance and reciprocity, a renewed commitment to reciprocate participation in each other's festivals. These ties between

\footnotetext{
9 In fact, in the 1950s, under the Vargas administration, a technical cooperation program had already been established with the FAO to conduct forestry surveys and find potential logging companies, and elaborated proposals for planned, systematic forest development in the Amazon. For more information see Ioris $(2014,2008,2005)$.

10 The FOA was the executing agency for PRODEPEF and the Brazilian Institute of Forestry Development (IBDF) was a governmental partner agency (UNDP/ FAO/IBDF/BRA-45 Project). The main objectives of the PRODEPEF were to technically and institutionally strengthen the IBDF and provide a wide range of information on forestry potential in Brazil to support national planning for forestry development (Ioris 2008; 2005).

11 Other population centres were also affected by the creation of the Flona Tapajós, like part of the municipality of Aveiro, and the São Jorge community, on the BR 163 .
} 
the communities also extended to kinship and familial relationships (godfather, godmother and similar intimate ties), as well as the collective work of clearing and cultivating of plots of land, accounts of which describe ritualised and festive encounters that extended for days.

The constitution of this territoriality, of this way of life, directly defied the creation of the Flona Tapajós, a project that formed part of the strategies of the accelerated modernisation projected for the Amazon in the 1970s, leveraged through the powerful imposition of control over national territory, both technical and political (Becker 1992; Schmink and Wood 1992). Its imposition on the Tapajós valley, however, required seizing the land from the inhabitants who were there. As a result, it created a field of disputes in which the endeavour was not only the appropriation of forest resources, but also the imposition of categories intended to disqualify any solid ties that the people might have in relation to a territoriality, a historicity of occupation, or belonging to a more complex or differentiated socio-cultural organisation. Its effects were intended to contribute to the definitive erasure of the ethnic references that continued to persist in the last 25 years of the twentieth century and, therefore, to the first efforts to seize their territories.

\section{III.i. From the cleansing operation to the traditional populations}

Although the Flona Tapajós is inserted in a scientifically based modernisation programme aimed at accelerating the economic growth of the Amazon, promoted within the sphere of the geopolitical project of dictatorial military governments, its creation dispensed with any communication with the people from the local communities. Indeed, they only became aware of its existence when the procedures to remove them from their territory were already underway. At that time, national forest legislation did not allow permanent residents to remain within their boundaries. Thus, the officials of the Brazilian Institute of Forestry Development (IBDF), ${ }^{12}$ the environmental management organ of the national forests at that time, began the process of removing people from the sixteen communities that existed along the right bank of the Tapajós River, together with the remaining population centres inside the Flona Tapajós. Filled with surprise and indignation, people from these communities reacted to attempts at forced removal, and undertook various forms of resistance to remain in their territories. This struggle lasted for more than two decades, forming an intense field of disputes, with different moments of conflict intensity and tension over time.

Measures to remove people from these sixteen communities within the boundaries of the Flona Tapajós began shortly after the signing of the founding ordinance, as is clear from official correspondence (Ofício no. 105/74) by the then head of the IBDF base in Santarém, Ben-Hur Borges, of June $17^{\text {th }}$ 1974, four months later. The letter, addressed to the State Commissioner of the IBDF, in Belém, Para, advised him of the procedures that had been taken "to definitively regulate the Flona Tapajós". First, it stated that public notice had been given "by the local broadcaster explaining the purposes of this to the rural people, particularly those established within the limits of the FLONA [Tapajos], and the steps to be taken by the inhabitants". Second, the letter reported that land lots had already been requested from the regional coordinator of the National Institute of Colonisation and Agricultural Reform (INCRA) for a settlement project, to be implemented on the other side of the BR-163, which were destined for people who would be removed from the inside the Flona Tapajós. The document referred to these people as "settlers" [colonos] and the measures of expropriation as a "cleansing operation". According to them, the lots would be "for settlers who are displaced by the cleansing operation. Such lots are already reserved and simply require the identification of the settlers and their subsequent removal".

12 The IBDF was created in 1967 
In general, Indians and non-Indians from various communities to whom I spoke in my surveys concerning how they found out about the creation of the Flona Tapajós told me that they only came to know about it when IBDF officials arrived at their homes to do surveys of their proprieties, and only after the officials had asked all the questions about their assets. Thus, they simultaneously learned about the creation of the Flona Tapajós, and that it entailed removing them from their lands. The reason for the official's survey was to finance the payment of indemnities that they would receive for their improvements. These IBDF actions provoked reactions in the communities, who began to articulate in defence of remaining on their lands, in a context of struggle strongly marked by the authoritarianism dictated by the military regime (Leroy 1991). The government's resolve in imposing displacement on people who resisted leaving led to a number of repressive and prohibitive measures against their sustenance and productive activities, such as banning access to timber forest resources, planting smallholdings and hunting, and included police coercion, low-flying helicopters, and other forms of intimidation.

Regardless of the differences in the historical configurations and socio-political and cultural organisations of the sixteen communities that lived in the area where the Flona Tapajós was established, most of the people were part of a long history of occupation, where they developed a territoriality based on a system of common use of land and resources. In general, they were identified as caboclo, ${ }^{13}$ although they never referred to themselves by this denomination, since it is considered offensive. When I visited the communities for the first time in 1996, people identified themselves in various forms, such as "rural workers", "descendants of Indians", "children of the Tapajós", or, more commonly, as belonging to a particular community: "I'm from the Piquiatuba community"; "I'm from the Taquara community"; "I'm from the Acaratinga community"; and so on. At no point did I hear people identifying themselves as "caboclo" or "cabocla", except for certain community leaders, while attending meetings to discuss land possession and regularisation. In these moments they laid claim to territorial rights, justifying such claims because they were "caboclos of the land of the Tapajós" or, more frequently, because they were "children of the Tapajos".

Regarding their ancestry, people in the communities attributed this to various origins, mostly identifying themselves as descendants of indigenous peoples, although they generally did not specify an ethnic group, rather mentioning that "my grandfather" or "my grandmother was Indian". Sometimes they mentioned the place of origin of their ancestors, when the place was different to where they lived at that time: "my father was an Indian from the Arapiuns River", "Indian from Alter do Chão", and so on. Sometimes they expressed their indigenous origins by saying: "my grandmother spoke only the indigenous language". It was also common to attribute mixed origins: "my grandfather was the son of an Indian with Portuguese", "Indian with Cearense". Maria, from Piquiatuba, explained to me that "in my family we have a little of everything: Indian, Portuguese, Cearense, Paraense, all mixed together". Besides these, there are those who acknowledge that they are of indigenous origin, but do not see themselves as indigenous any longer: "It is true that we are all descendants of Indians, but it is no longer in our blood". The three indigenous communities of Taquara, Marituba and Bragança, mentioned above, only began to identify themselves and articulate politically as belonging to the Munduruku ethnic group in 1998.

In official terms, as we have seen in the above-mentioned document, they were indiscriminately identified as "settlers" who were destined to undergo a "cleansing operation" to remove them from their lands. The emphasis on "cleansing" imposed by the first land regularisation efforts of the Flona Tapajós seems to be based on practices widely applied previously in the pacification strategies of the Cabanagem revolt, commanded by Marshal Francisco José de Souza Soares d'Andrea. He emphasised that: "The Amazon

13 In the Amazon region, caboclo is a controversial and multifaceted, social category applied to mixed societies that originated from pre-colonial Amerindian descendants and poor Europeans. Some scholars have used the term caboclo to refer to the typically Amazonian peasantry (Harris 1998; Nugent 1993; Parker 1985; Lins e Silva 1980; Wagley 1976). 
and the entire route by water from Cameta to the mouth of this river needs to be cleansed, and it has to cost some lives" (emphasis added). The records show that it was not just some lives, as 40,00o were officially declared dead, equivalent to $25 \%$ of the entire population of Grão-Pará14 (Bessa Freire 2011; Menéndez 1992; Parker 1985; Moreira Neto 1988). Almost 150 years later, the native groups of the Tapajós face a new version of cleansing, aimed at removing them from their territories to make way for the modernising project of the timber industry in the region.

The unproductive efforts to remove people from within the boundaries of the Flona Tapajós on the right bank of the Tapajós River, due to the strong resistance, led to successive demands for more information or official letters and ordinary requests regarding questions about these domestic groups in these communities, producing many documents. In these documents is where we mainly find the different ways the people were identified. After being initially referred to as "settlers", other denominations emerge, including: squatters, occasional occupants and sometimes intruders in the forest reserve or riverside caboclos, which annul and disqualify more solid socio-cultural or territorial ties that the people may have with the land they live on.

Prior to the creation of the Flona Tapajós, the sixteen communities had few, dispersed links among them, primarily deriving from kinship ties and reciprocities in cultivation, trade, and religious or ludic festivities. The process of the creation and implementation of this forest reserve and the attempts to displace people fostered a closer, politically organised relationship among these communities, with the main articulator being the Rural Workers Union of Santarém and the support of the Catholic Church. In this process of mobilisation and struggle, the communities came to constitute a political unit with a specific interest in avoiding removal from their lands (Ioris 2014; 2005).

The clashes between these communities and government agencies to prevent their removal lasted for more than two decades, with various forms of confrontation. However, in the mid-199os, in the context of the Pilot Program for the Protection of Brazilian Tropical Forests (PPG-7) $)^{15}$, a new framework of political and ideological forces mainly concerning discussion of the participation of the Amazonian peoples in environmental conservation policies, reversed the decision to remove peasant domestic groups considered "traditional populations" from inside national forests. The implementation of the PPG-7 began in the Flona Tapajós in 1995, with the objective of developing and testing models of conservation and sustainable use of natural resources in Amazonian forest reserves, with an emphasis on civil society participation. The prominence of participatory methodologies in the PPG-7 led a diverse set of actors and agencies, who were in some way related to the Flona Tapajós (representatives of the communities, grassroots social organisations, environmental NGOs, local government and national organs, and multilateral agencies like the World Bank and GTZ ${ }^{16}$ ), to discussions and negotiations that evinced the problematic of conflicts with communities within the reserve, which had already lasted for two decades. The conclusion of the preparatory work defined the resolution of land conflicts as a condition for the implementation of the PPG-7 in the Flona Tapajós (Fatheuer 1998).

A work plan was then agreed, which provided for procedures for conflict resolution, including studies to define an area for these communities that should be excluded from the Flona boundaries. Thus, the work with the communities was developed through a sequence of activities, involving discussion workshops and

\footnotetext{
14 In Santarém, Menendez (1992: 292) records that "the population of this village, which was 6,00o before the revolt, had fallen to 4,00o (including whites, black slaves and Indians, mainly Munduruku and Mawé)".

15 The Pilot Program for the Protection of Tropical Forests, (PPG-7) was launched during the United Nations Conference on Environment and Development, Eco-92, in Rio de Janeiro. The PPG-7 funding was provided by the Group of Seven (or G7) countries with the largest advanced economies in the world, and administrated by the World Bank through the Rain Forest Trust Fund Resolution. For more comprehensive analysis of PPG-7 implementation in Flona Tapajós, see Ioris $(2014 ; 2005)$.

16 The German Organisation for Technical Cooperation (GTZ)
} 
socio-political, economic and environmental surveys, which supported the elaboration of a proposed area to be assigned to them. In 1996, a Bill was passing through the Brazilian Congress to exclude the areas where populations lived inside the Flona Tapajós, including those of the communities, at that time numbering eighteen, which was expected to propose the limits that would be established (IMAFLORA/IBAMA 1996).

Representatives of the IBAMA, however, disagreed with the proposal to reduce the Flona Tapajós boundaries and began defending the permanence of the communities inside the reserve, where they would be provided an area of use, whose extension should be designated through the elaboration of the management plan. The new position taken by IBAMA technicians reflected the changes that were underway in the national forests legislation through the new version of the National System of Conservation Units (SNUC) ${ }^{17}$ sanctioned in 2000. In this version of the SNUC, the text of article 17 concerning national forests expanded the concept of this category of reserve, designating it as "sustainable multiple use of natural resources", and not just for timber exploration, as it had previously described. It also stated that "traditional populations that inhabited it when it was created were allowed to remain", provided that they did so in accordance with the regulations and management plan of the unit. In addition to national forests, the SNUC also considered the category of 'traditional population' in two other classes of reserves: Sustainable Development Reserves (RDS) and Extractive Reserves (RESEX). In reference to Extractive Reserves, Article 18 mentions "traditional extractive population".

As a result, the communities of the Flona Tapajós that had been previously identified as 'settlers', 'caboclos', 'squatters', 'occasional occupants' or 'riverside communities', were now identified as 'traditional populations" and, thus, their permanence was 'allowed' within the reserve, ensuring the right to continue on their lands, even though these would be under the control and management of the state environmental agency. In this new conformation, the IBAMA made efforts to ensure that the areas of use were incorporated into the management plan of the Flona Tapajós, and managed to remove the exclusion of the area of these communities from the Bill that was under discussion in the Brazilian Congress. This change in the reserve legislation removed the threats of expropriation, but on the other hand, it frustrated the expectations of those who wanted to end IBAMA's interference with their lands.

The majority of the people in the communities ended up conforming to the categorisation of traditional population and having their territories under the control of the environmental agency. However, three communities inside the boundaries of the Flona Tapajós, Taquara, Bragança and Marituba, rejected this form of identification and began designating themselves as belonging to the Munduruku ethnicity, constituting an ethnic and culturally differentiated group, with demands for the recognition of their lands as "indigenous".

\section{Indigenous peoples in the context of "Special Zones of Cultural Interest"}

At the same time that the Flona Tapajós administration was making efforts to bring about changes to the incorporation of those groups that came to be recognised as 'traditional populations', leaders of the community of Taquara followed the course of the upper Tapajós in 1998, and sought out the offices of the Regional Administration of the FUNAI in Itaituba. During that visit they handed over a document to the regional administrator requesting clarification on the right to validate their lands as 'indigenous'. A few days later, the FUNAI regional administrator visited them in Taquara and sent requests to the FUNAI Land Affairs Directorate in Brasilia, advocating the formation of a working group to conduct anthropological studies, with the objective of regularising those lands. He also sent official letters to the IBAMA, the INCRA

17 The National System of Conservation Units (SNUC) covers the legislation that governs the creation and implementation of environmental reserves in Brazil. Federal Law no. 9,985, of July 18 th 2000. 
and the Federal Public Prosecutor, informing them of the existence of these Indians and the actions being taken by the FUNAI (Almeida 2001).

This visit to the FUNAI Administration occurred soon after the death of Pajé Laurelino, patriarch of the largest family nucleus in Taquara and the main political-religious leadership of the community. After his death, in May 1998, the Taquara Indians began a cultural re-elaboration movement, reclaiming their ritual manifestations, their language, body paintings, and they began identifying themselves as belonging to the Munduruku ethnicity. In terms of organisation and political representation, they began articulating around the cacique, abandoning the previous structure based on a community 'president', which they understood as a condition imposed by the "whites". Several events marked the beginning of this process of ethnic reassertion. In October, during the celebrations of Our Lady of Aparecida, the patron saint of the community, they promoted an "Indigenous Mass", and as the New Year began (1999), the "First Indigenous Encounter". Both events were attended by guest representatives from several neighbouring communities, from NGOs, from the Federal University of Pará (UFPA), from the municipal administration and politicians (council members). In 2000, the community leaders participated in the manifestations of the 500 years of the discovery of Brazil in Porto Seguro, Bahia, and when they returned, they mobilised by creating the Tapajós-Arapiuns Indigenous Council (CITA).

In the wake of this movement for ethnic reaffirmation taking place among the Taquara Indians, people from Marituba and Bragança, who had accompanied the initial discussions and mobilisations, also began to identify themselves as belonging to the Munduruku ethnicity. In the context of the Flona Tapajós, these three communities began to form a new and distinct socio-political and ethnical unit, which was distancing itself from the remaining groups found inside the forest reserve that had come to be recognised as 'traditional populations'. Claiming that they belonged to an ethnically organised collectivity, these three communities distanced themselves from groups with whom they shared a history of struggles in defence of their territories, creating a schism between them, between Indian and non-Indian, or more precisely, between 'Indian' and 'traditional populations'. Thus, two culturally and politically organised groups formed within the Flona Tapajós, the schism that was established between these two social groups distinguished them and divided them with regard to their forms of identification, of socio-cultural and political organisation and, particularly, in their claims for land regularisation.

In this new situation, the Indians also broke off relationships with the administration of the Flona Tapajós, refusing to participate in any negotiations or activities promoted by the representatives of the reserve. They began claiming the regularisation of their lands from the FUNAI, which, in response, set up a technical working group in January 2001 to conduct surveys on the indigenous people in the lower Tapajós. Based on this survey, studies to identify the delimitation of the indigenous lands of Taquara, Bragança and Marituba were suggested, which were conducted in 2003, and the creation of two Indigenous Lands was proposed: the Munduruku-Taquara Indigenous Land and the Bragança-Marituba Indigenous Land (Ioris 2009). The declaratory ordinances of both indigenous territories were signed by the Minister of Justice in 2015.

In addition to these procedures for official recognition of these lands, some initiatives implemented by local authorities are worth highlighting. In the municipality of Belterra ${ }^{18}$, these attentions were reflected in the forestry planning and in the actions of its Participative Master Plan, elaborated during 2006 and sanctioned in February 2007 (Law no. 131). With the participation of indigenous representatives in the elaboration work, article 37 of the Municipal Master Plan established that the lands of the Munduruku of Bragança, Marituba and Taquara constitute "Special Areas of Cultural Interest". Soon after, the municipality

18 The municipality of Belterra was created in 1996, partitioned from the boundaries of the municipality of Santarém. 
of Belterra created the Indigenous Coordination, assigned to the Planning and Management Secretary, to deal exclusively with the interests of the Indians of the municipality. In addition, elementary schools in Bragança, Marituba and Taquara have become recognised as 'indigenous schools' and, in principle, provide differentiated education. In this context, the Indians also created the Munduruku Indigenous Council of Belterra (CIMB), which began functioning in December 2007, during the Many Festival, an event that occurs annually among the Munduruku of Taquara.

Accordingly, mobilised to reaffirm their ethnic belonging, the Munduruku of Taquara, Bragança and Marituba rejected the attribution of 'traditional population', resulting from the new legislation of the SNUC, and rejected the model of land occupation that was granted them under the condition of "traditionals allowed" to live inside a national forest boundary.

\section{IV.I. Allowing the permanence of "traditional people": relationships of dependence and unequal power}

Having accompanied this process of ethnic reaffirmation from the outset, the inquiries that came to me from people in local groups, government representatives and academics regarding the motivations that instigated the movement among the Indians were not uncommon. People expressively questioned, seeking to confirm whether the indigenous people had adhered to the movement for strictly utilitarian motivations, to ensure access to "land". Unaware of the histories of struggle of these communities, it seemed difficult for them to understand that the ethnic reaffirmation movement among these three indigenous communities in the Flona Tapajós erupted when they were apparently celebrating victory, following a long dispute to avoid expulsion from their lands, just as they were recognised as "traditional populations" and were allowed to remain within the boundaries of this forest reserve. In this case, it was precisely when the legislation changed and allowed these populations to remain on their lands that these groups of communities began the process of reclaiming old cultural traditions and identifying themselves as bearers of differentiated ethnic identities. It was only when the threat of expulsion from their land had been dissipated in the Flona Tapajós, when they came to be regarded as "traditional populations", that these groups once again opposed an officially ascribed definition and demonstrated the character they intended for themselves and the way they envisaged being identified.

As highlighted in previous studies (Ioris 2014, 2009), understanding the emergence of this ethnic reaffirmation movement is also to bear in mind the emergence of the notion of "traditional population" and its formulation as a classificatory category of social groups that could benefit from the policies of creating environmental reserves. As a number of authors have presented, this notion was forged in the international environmental debate on the presence of human groups in environmental conservation areas, and especially concerning the conflicts arising therefrom (Lima 2002; Barretto 2006; 2001; Diegues 1998; Vianna 1996). For the most part, environmental reserves around the world were created in the territories of social groups that traditionally exercised forms of common resources use, which, like the communities of the Flona Tapajós, were to be displaced from their lands to make way for the reserve project. The resistance of these groups composed endless processes of conflict, such that the situations, on the one hand, do not allow them full access to the resources they previously had, and on the other, they prevent the full implementation of the environmental reserve.

Accompanying the problematic in Brazil, particularly in relation to the advent of extractive reserves in the Amazon, the adoption of the notion of 'traditional population' occurred in the 1990s, designating specific and distinct social groups that were devoid of the legal recognition that guaranteed them rights over the lands that they historically inhabited. In this sense, Barretto (2006: 109) highlights the ambivalence of the notion: "because at the same time that it operates as a residual category in a negative sense, encompassing everything 
that is not indigenous or quilombola, or rubber tapper, it covers and comprises all these categories of social groups - and many others - whose cultural distinctiveness is better expressed in terms of specific territorialities".

Officially, the term 'traditional population' was first used with the creation of the National Council of Traditional Populations (CNPT) ${ }^{19}$ in 1992. However, its definition was only elaborated later, during the work for their incorporation into the new SNUC, approved in 2000, in order to understand and regulate the situations of population groups in areas of environmental reserves, those that were classified as 'sustainable use conservation units'. Undoubtedly, the incorporation of 'traditional populations' expressed a significant change in the conception and field of action of the environmental reserves, which until then had prohibited any form of human occupation, the reason for the long conflicts with populations inside the Flona Tapajós, and all other conservation units in the Amazon.

However, the definition of 'traditional population' in the current version of the SNUC is diluted among several articles that define and regulate the respective reservations. It is not mentioned, for example, in the article referring to national forests, which has come to admit the permanence of such populations within their limits, but it is present in the article that refers to Sustainable Development Reserves (RDS). For the RDS, a 'traditional population' is defined as "those whose existence is based on sustainable systems of exploitation of natural resources, developed over generations and adapted to local ecological conditions and which play a fundamental role in the protection of nature and the maintenance of biological diversity". In the article on Extractive Reserves, the definition of "traditional extractive populations" appears, defining them as those "whose subsistence is based on extractivism and, additionally, on subsistence agriculture and the creation of small animals".

In all these definitions in the SNUC text, the notion of 'traditional population' is strongly linked to ecological criteria, to environmental sustainability, as established by its management plans, and not to socio-cultural criteria, leading to compromised forms of identification, of the organisation of spaces, and of the appropriation of resources. Thus, strongly linked to environmentalist conceptions and formulations elaborated in the modes of scientific knowledge and not of local social groups, the notion of "traditional population" present in the SNUC subjugates the ways in which these groups organise and relate to natural resources to parameters that are alien to their socio-cultural universe. This notion, as Barretto (2006) pointed out, conspires against the autonomy and self-determination of these peoples, since it conditions their future to a rationality of forest policy that is exogenous to them, formulated on the basis of unequal power.

Therefore, in relation to national forests, which, under the regulation of the SNUC, came to allow the presence of "traditional populations", the notion as formulated tends to reinforce mechanisms that nullify the autonomy of social groups on their own lands; even when allowed to remain, they are subject to the management plans of the reserve. There is no full recognition of the rights of these populations over the lands they historically occupy, rather there is an 'acceptance' of their permanence, since it is conditioned to what is proposed in terms of the objectives for the reserve. So a relationship of dependence and unequal power is established a priori, which neutralises the legitimacy of the demands of these social groups regarding the territories and the resources they use. Moreover, insofar as this permanence occurs in "accordance with the management plan of the reserve", and considering that the objectives of the national forest management plans are forest exploitation for commercial timber production, this compliance implies forms of organisation and appropriation of the resources of the said 'traditional populations' with the forms of promotion of management and logging. As Almeida (2004: 10) points out: "the fact that the government has incorporated the expression 'traditional populations' in the relevant legislation and in the bureaucratic-administrative apparatuses ... does not exactly mean an absolute compliance with the claims made by

19 The National Council of Traditional Populations (CNPT) was initially created to regulate the creation of Extractive Reserves, which were being initiated due to the demands of the rubber tappers' movement in Acre and Rondônia. 
these social movements, therefore, it does not mean a resolution of conflicts and tensions concerning the intrinsic forms of appropriation and common use of natural resources".

The movement of ethnic and cultural reaffirmation that arose among the indigenous peoples in the Flona Tapajós can be understood as a reaction that rejects this form of identification as a "traditional population", which was being officially adopted. Just as they reacted to the initial attempts to categorise them as "settlers", "squatters", "occasional occupants", or "riverside caboclos", the three indigenous communities also rejected this new formulation projected onto their ways of life through the notion of "traditional population", which simplified a diversity of cultural situations, naturalising social groups to establish an instrumental relationship that is obliged to respond to the objectives of the environmental reserve management plans. They reacted by seeking the re-elaboration of the future they intended in the formulations and understandings of their ethnic origins and trajectories, through which they could exercise the particular way of life they have sought in all these years, by engaging in various forms of struggle, and which the categorisation of 'traditional population', defined in the new version of SNUC, once again tended to diminish. It is curious, however, that they reacted precisely to the more radical efforts among the categories imposed on them throughout the history of the Flona Tapajós, that is, the definitive elimination of the ethnic references that still persisted.

\section{A new memory regime: Answering the call that comes through cassette tapes}

Understanding the emergence of the ethnic reaffirmation movement as a reaction to the category of traditional population still does not explain why the other communities located inside the Flona Tapajós did not react in the same manner as Taquara, Marituba and Bragança, since they share historical processes of occupation and the same land-use system, and some of them still share strong kinship ties. From the perspective of the Taquara people, the first to embark on this ethnic adventure, their emergence is closely related to the death of their main political and religious leader, Laurelino Floriano Cruz, head of an extended family who dedicated his life to treating and healing people, and whose gift was widely recognised throughout the lower Amazon.

Laurelino was born on the upper Arapiuns River, a tributary of the Tapajós, where the Maró Indigenous Territory is located. He identified as Kumaruara Indian and defined himself as an "earth doctor". It was very common to hear statements from people in the region of the Tapajós like: "what the medical doctor can't handle, only Laurelino can heal". In addition to receiving an immense number of people in the community of Taquara, who flocked from many places to be treated, Laurelino also travelled once a month to Santarém, where dozens of people lined up in front of the boat docked at the city pier, waiting to be attended to by him.

In addition to being recognised as the last great healer of the lower Tapajós, Laurelino was also head of a large family nucleus that constituted and shaped the Taquara community, which based its entire social organisation and dynamics on his practices as a healer. It was right after his death in May 1998 that the process of ethnic reaffirmation was initiated. A few months before his death, Laurelino had recorded long interviews on cassette tapes with Florencio de Almeida Vaz, a Maytapu Indian, Franciscan priest, anthropologist and professor at the Federal University of Western Pará (UFOPA), in which he recounted his life story, his work curing people, and ended by asking their children and grandchildren not to forget their "indigenous culture". These tapes were left with his relatives who, in the ensuing mourning after his death, spent time listening to them together. From the voice they heard telling them not to forget their "indigenous culture", came the impulse to respond to the call not only to not forget, but to live the "indigenous culture" fully. As one of Laurelino's sons explained to me: "After my father's death, we spent a long time listening to the tapes, one tape after the other. We began to wonder about various things. If our father's wish was that we should not 
forget our culture, that we recognise our culture, that we are really indigenous, then why do we not recognise that we are indigenous? Is it to do with shame? Then, let's put our aside our shame and be who we really are".

The prompt attention they gave to that call, which they heard successively on the obsolete cassette tapes, demonstrated that non-forgetting, permanent remembrance, would be renewed in the lived and embodied experience of "indigenous culture". The drama experienced by Taquara people following the death of Laurelino refers to the analyses that Turner (1974) elaborated to address events that caused crises and changes that are experienced by human collectives, defined as 'social dramas': these "are units of aharmonic or disharmonic process, arising in conflict situations" (p.37). Thus, he highlighted the phase he called redressive action, which succeeds the stages of crisis in social organisations. He examined the transition phase, or threshold phase of the passage, and the spontaneous development of communities that share specific characteristics, which he calls "communitas". Understanding that crisis stages are "turning points or moments of danger and suspense" that affect social organisations, Turner observes that "in order to limit the spread of the crisis, certain adjustive and redressive 'mechanisms,' [...] informal or formal, institutionalized or ad hoc, are swiftly brought into operation by leading or structurally representative members of the disturbed social system" (p.39). For the author, it is precisely in this "redressive phase that both pragmatic techniques and symbolic action reach their fullest expression" (p.41), and its most complete expression certainly lies in those of the ritualisation of culture.

The perspective that Turner provides concerning the dynamics expressed in conflict situations, danger or suspense, experienced by social groups, has been instrumental in my thinking regarding the internal motivations that instigated the ethnic and cultural reaffirmation movement among the Taquara people, and which stimulated the prompt and immediate response to the call heard through repeatedly listening to those tapes. Understanding, therefore, the call that was really important to hear, even though it was not explained on the tapes, but that was answered so decisively nevertheless.

The conformation of the Taquara community was established over decades and it remained united under the leadership of Laurelino, whose shamanistic practices founded the basis of the socio-political and cultural relationships of the community, both internally and externally. In Taquara, people who were not his direct descendants were there for reasons that stemmed from his healing work. As such, his death caused an irreplaceable loss in terms of political and religious leadership, leaving an empty space in the organisation of these relationships. This space, this aharmonic event, can be understood as a threshold period for the community, "a threshold between more or less stable phases of the social process" (Turner 1974: 39). It was precisely at this moment, on the threshold that followed Laurelino's death, that the Taquara community began to re-establish connections with ancient indigenous traditions, in which shamanic practices and cosmologies were expressed in their most elaborate form. This direction, in the sense of asserting ethnic belonging and indigenous cultural traditions can thus be apprehended as part of these mechanisms that Turner highlights as adjustments or repairs that are put in place to overcome social crises, in this case, caused by Laurelino's absence. The emptiness caused by his death and the imminent crisis caused by the loss of his highest leadership (political-religious) were overcome by the reclamation and re-elaboration of their ethnic origins and trajectories, forms of organisation and political representations, and ritual performances.

While alive, Laurelino and his shamanic works were the embodiment of the symbolic practices and cosmologies that linked them to an indigenous past; without it, the continuity of this connection, the non-forgetfulness, depended on the entire group assuming the task of keeping them referential and active. Laurelino's call for non-forgetfulness was, in fact, a call for a new memory regime that would not let them forget the particularity of their histories. As Berger notes (1963: 68-69), "every rite of passage is an act of historical interpretation and every wise old man is a theorist of historical development", and "memory itself is a reiterated act of interpretation". The constancy of the memory of their indigenous culture, however, would 
not be a mere exercise of abstraction, but imprinted and renewed in the experience of their daily practices, in their political organizations, as it is in their bodies. It is in these lived practices that the Indians - or rather, the Munduruku - re-inscribe themselves in the history of the lower Tapajós and in negotiations of power. The same is true of the Borary, the Tapajó, the Maytapu, the Arapium, Jaraki, Kumaruara and others who had been deleted from the official historiographical narrative.

\section{Conclusion}

Reflecting on the processes of ethnogenesis that shaped themselves among the Munduruku, as well as among the other indigenous peoples in the lower Tapajós, as constituting a new memory regime to confront the dominant historiographical narratives that exclude their protagonisms, allows us bring to the fore a set of questions that must be considered. First, it allows us to problematise the construction of these narratives, which, although elaborated in different memory regimes, produced an erasure of the indigenous peoples, or, as Pacheco de Oliveira (2016) would define it, imagining them as having dissolved in the colonisation. At the intersections of the production of these narratives and the networks of power that support them, we can understand the ways in which the indigenous peoples in the lower Tapajós were historically the object of official programs aimed at eradicating ethnic and cultural alterities, in order to transform them into a workforce and appropriate their territories (Ioris 2014; 2005). Efforts to forcefully remove people from the Flona Tapajós in the 197os and 1980s, and Judge Portela's decision regarding the Borary of the Maró Indigenous Territory in 2014, illustrate more recent examples of the ways in which this construct has continued to operate and reproduce in diverse historical situations, by describing them as "generic Indians", as "Tapuia descidos", as "caboclos", as "occasional occupants", or "traditional riverside dwellers", always of minimal relevance in the local political economy, and of minimal historiographical or anthropological interest.

However, critical for memory regimes, this perspective also makes it possible to understand the ways in which the indigenous peoples themselves have sought to construct memory today, as artisans of another memory architecture, which has opposed those that disregarded not only their protagonism, but also their very existence. Narratives that always seemed to me to be well understood by the Indians. Assis, then the vice-Cacique Munduruku of Taquara, often emphasised in our conversations that "we never ceased to be Indians, it was the whites who stopped seeing that we were Indians". The ethnographic situation allows us to understand the motivations (material and ideological) internal and external, leveraging these processes of ethnic and cultural re-elaboration, instituting a new memory regime that emphasises and substantiates their alterity, in each of the groups. Although the various situations of ethnogenesis observed in the lower Tapajós region should be understood in their particularities, it is also necessary to consider the broader socio-political processes that affect them as a whole.

Received: October 22, 2017

Approved: March 03, 2018

Translated by: Phil Badiz 


\section{References}

ALMEIDA, Alfredo W. B. 2004. “Terras tradicionalmente ocupadas: processos de territorialização e movimentos sociais". Revista Brasileira de Estudos Urbanos e Regionais, 6(1): 9-32.

. 2008. Terras tradicionalmente ocupadas: terra de quilombos, terras indígenas, "Babaçuais Livre", "Castanhais do Povo", Faxinais e Fundos de Pasto. 2a․ ed. Manaus: Editora da Universidade do Amazonas.

ALMEIDA, Rita H. 2001. Relatório de viagem ao rio Tapajós. FUNAI, portaria n ${ }^{\circ}$ 84/2001. Brasília. Mimeo.

AMOROSO, Marta Rosa. 1992. "Corsários no caminho fluvial: os Mura no rio Madeira”. In: Manuela Carneiro da Cunha (org.), História dos índios no Brasil. São Paulo: Cia. das Letras. pp. 297-310.

BAENA, Antônio Ladislau Monteiro. 2004 [1839]. Ensaio Corográfico sobre a Província do Pará. Brasília: Senado Federal, Conselho Editorial, 432 p. (Edições do Senado Federal; v. 30). Disponível em: http://www2. senado.leg.br/bdsf/handle/id/1097

BARRETTO, Henyo T. 2006. "Populações tradicionais: introdução à crítica da ecologia política de uma noção". In: C. Adams; E. Murrieta; W. Neves (org.), Sociedades caboclas amazônicas: modernidade e invisibilidade. São Paulo: Annablume. pp. 109-143.

- 2001. Da nação ao planeta através da natureza: uma abordagem antropológica das Unidades de Conservação de Proteção Integral na Amazônia brasileira. Tese (Doutorado em Ciência Social), São Paulo, Universidade de São Paulo.

BARTOLOMÉ, Miguel Alberto. 2006. "As etnogêneses: velhos atores e novos papéis no cenário cultural e político". Mana. Estudos de Antropologia Social, 12(1): 39-68.

BATES, Henry W. 1979 [1863]. Um naturalista no rio Amazonas. Belo Horizonte: Editora Itatiaia/ USP.

BECKER, Bertha K. 1992. "Repensando a questão ambiental no Brasil a partir da geopolítica”. In: M. C. Leal (ed.), Saúde, ambiente e desenvolvimento: uma analise interdisciplinar. São Paulo: HUCITEC. vol. 1. pp. 127-152.

BENJAMIN, Walter. 1985. Obras escolhidas. Volume I: magia e técnica, arte e política. São Paulo: Editora Brasiliense.

BERGER, Peter L. 1963. Perspectivas sociológicas: uma visão humanistica. Petrópolis: Editora Vozes.

BESSA FREIRE, José R. 2011. Rio Babel: a história das línguas na Amazônia. Rio de Janeiro: Editora da UREJ

BOLANOS, Omaira. 2008. Constructing indigenous ethnicities and claming land rights in the lower Tapajós and Arapiuns region, Brazilian Amazon. Tese (Doutorado em Antropologia), University of Florida, Gainesville, FL. CLIFFORD, James. 1988. "Identity in Mashpee”. In: The predicament of culture, twentieth-century ethnography, literature, and art. Cambridge, MA: Harvard University Press. pp. 277-346.

CONDREAU, Henry. 1977 [1897]. Viagem ao Tapajós. Belo Horizonte: Livraria Itatiaia.

DI PAOLO, Pasquale. 1990. Cabanagem: a revolução popular na Amazônia. Belém: CEJUP.

DIEGUES, Antonio C. 1998. O mito moderno da natureza intocada. São Paulo: Hucitec,

FATHEUER, Thomas. 1998. "Novos caminhos para a Amazônia? O Programa Piloto do G-7: Amazônia no contexto internacional". Série Cadernos de Proposta, 1(2): 5-46. Rio de Janeiro: FASE/SACTERS.

HARRIS, Mark. 1998. "What it means to be Caboclo: some critical notes on the construction of Amazonian Caboclo Society as an anthropological object."

Critique of Anthropology, 18(1): 83-95.

. 2010. Rebellion on the Amazon: the Cabanagem, race and popular culture in the North of Brazil. Cambridge: Cambridge University Press.

IMAFLORA. 1996. Plano diretor e mapeamento comunitário da margem direita do Tapajós. Programa Piloto para Proteção das Florestas Nacionais Tropicais do Brasil (PPG-7). Mimeo.

IORIS, Edviges M. 2005. A forest of disputes: struggles over spaces, resources and social identities in Amazônia. Tese de Doutorado, University of Florida, Gainesville-FL. 
. 2008. "Na trilha do manejo científico da floresta tropical: indústria madeireira e florestas nacionais".

Boletim do Museu Paraense Emilio Goeldi. Ciências Humanas, 3(3): 289-309.

. 2009. "Identidades negadas, identidades construídas: processos identitários e conflitos territoriais

na Amazônia”. Ilha (Revista de Antropologia), 11(1 e 2): 219-164.

. 2011. "Fragmentos que fazem diferença: narrativas indígenas na reconstrução do passado e das

identidades étnicas". Antropologia em Primeira Mão, n. 125.

. 2014. Uma floresta de disputas: conflitos sobre espaços, recursos e identidades sociais na Amazônia.

Florianópolis: Editora UFSC.

. 2017. "De ruínas e fragmentos: narrativas e reflexões indígenas na reconstrução do passado e das

identidades étnicas". In: Ricardo Verdum; Edviges M. Ioris (orgs.), Autodeterminação, autonomia territorial e acesso à justiça: povos indígenas em movimento na América Latina. Rio de Janeiro: Associação Brasileira de Antropologia (ABA). pp. 229-251.

LEROY, Jean P. 1991. Uma chama na Amazônia. Rio de Janeiro: Vozes/ FASE Editora.

LIMA, Deborah M. 2002. "A construção histórica do termo caboclo: sobre estruturas e representações sociais no meio rural Amazônico". Novos Cadernos NAEA, 2(2): 5-32.

LIMA, Leandro M. 2015. No Arapiuns, entre verdadeiros e - ranas: sobre os espaços, as lógicas, as organizações e os movimentos do político. Tese (Doutorado em Antropologia), São Paulo, Universidade de São Paulo.

. 2008. Rios Vermelhos: Perspectivas e posições de sujeito em torno da noção de cabano na Amazônia em meados de 1835. Dissertação (Mestrado em Antropologia), São Paulo, Universidade de São Paulo.

LINS E SILVA, Tatiana. 1980. Os curupiras foram embora: economia, política e ideologia em uma comunidade amazônica. Dissertação (Mestrado em Antropologia), Museu Nacional, Universidade Federal do Rio de Janeiro, Rio de Janeiro.

MEGGERS, Betty. 1977. Amazônia: a ilusão de um paraíso. Rio de Janeiro: Civilização Brasileira.

MENÉNDEZ, Miguel. 1981. “Uma contribuição para a etno-história da área Tapajós-Madeira”. Revista do Museu Paulista (Nova Série), 28: 289-385.

. 1992. "A área Madeira-Tapajós. Situação de contato e relações entre colonizador e indígenas". In:

CUNHA, M. C. Cunha (org.), História dos índios do Brasil. São Paulo: Companhia das Letras. pp. 315-329.

MORAN, Emilio F. 199o. A ecologia das populações da Amazônia. Petrópolis (RJ): Editora Vozes.

MOREIRA NETO, Carlos A. 1988. Índios da Amazônia, de maioria a minoria (1750-1850). Petrópolis: Editora Vozes.

MOTA, Maria das Graças. 2006. Indígenas: organización y recuperación territorial. Un sueño de lucha en la Amazônia brasileña del bajo Tapajós. Dissertação (Mestrado em Antropologia), Pós-Graduação em Derechos Internacionales Indígenas y Recursos Hidrocarburíferos, FLACSO, Quito (Equador).

NIMUENDAJÚ, Curt. 1949. “Os Tapajó”. Boletim do Museu Paraense Emilio Goeldi, 10: 93-106.

NUGENT, Stephen. 1993. Amazonian Caboclo Society: an essay on invisibility and peasant economy. London: Berg.

PACHECO DE OLIVEIRA, João. 1999. A viagem da volta: etnicidade, política e reelaboração cultural no Nordeste indígena. Rio de Janeiro: Contra Capa.

. 2016. O nascimento do Brasil e outros ensaios: "pacificação", regime tutelar e formação de alteridades. Rio de Janeiro: Contra Capa.

PARKER, Eugene. 1985. The Amazon caboclo: historical and contemporary perspectives, studies in third world societies. Williamsburg: College of William and Mary.

PEIXOTO, Kércia Priscilla Figueiredo. 2017. "EU EXISTO": afirmação indígena e nomeação do racismo. Os Borari e os Arapium da Terra Maró, Amazônia. Tese (Doutorado em Antropologia), Universidade Federal do Pará.

RIBEIRO, Darcy. 1979. Os índios e a civilização: a integração das populações indígenas no Brasil Moderno.

Petrópolis: Editora Vozes.

SANTOS, Paulo R. 1999. Tapaiulândia. Santarém: Gráfica e Editora Tiagão. 
SCHMINK, Marianne; WOOD, Charles. 1992. Contested frontiers in Amazonia. New York: Columbia University Press.

SIDER, Gerald M. 1976. "Lumbee Indian cultural nationalism and etnogenesis". Dialectical Anthropology, 1(2): 161-172.

SMITH, Nigel J. H. 1980. "Anthroposols and human carrying capacity in Amazonia". Annals of the Association of American Geographers, 70: 553-566

TASSINARI, Antonella M. I. 2003. No bom da festa: o processo de construção cultural das familias karipuna do Amapá. São Paulo: EDUSP.

TURNER, Victor. 1974. Dramas, fields, and metaphors. Ithaca: Cornell University Press.

VALLE, Carlos Guilherme do. 1999. "Experiência e semântica entre os Tremembé do Ceará”. In: J. P de Oliveira (org.), A viagem de volta: etnicidade, política e reelaboração cultural no Nordeste indígena. Rio de Janeiro: Contra Capa Livraria. pp. 279-337.

VAZ, Florêncio de Almeida. 2010. A emergência étnica de povos indígenas no Baixo Rio Tapajós, Amazônia. Tese (Doutorado em Antropologia), Universidade Federal da Bahia, Salvador.

VELTHEM, Lucia Hussak van. 2003. O belo é a fera: a estética da produção e da predação entre os Wayana. Lisboa: Assírio \& Alvim.

VIANNA, Luciana P. 1996. Considerações críticas sobre a construção da idéia de população tradicional no contexto das Unidades de Conservação. Dissertação (Mestrado em Antropologia), Universidade de São Paulo, FFLCH, São Paulo.

WAGLEY, Charles. 1976. Amazon town: a study of man in the tropics. New York: Alfred A. Knopt.

\section{Edviges M loris}

Federal University of Santa Catarina (UFSC)

Department of Anthropology

Contact: emioris@gmail.com 